\title{
СЛОЖНОСТИ РАСКРЫТИЯ ИНФОРМАЦИИ О СВЯЗАННЫХ СТОРОНАХ
}

\author{
(C) 2021 Голышева Н.И. \\ кандидат экономических наук, доцент Департамента аудита и корпоративной отчетности \\ Финансовый университет при Правительстве Российской Федерации, Россия, Москва \\ E-mail: NGolysheva@fa.ru
}

Обеспечение раскрытия информации о связанных сторонах в финансовой отчетности компаний необходимо для того, чтобы заинтересованный пользователь мог наиболее объективно оценить финансовое положение компаний, учитывая возможные влияния связанных сторон.

Ключевые слова: учет, анализ, аудит, финансовая отчетность, связанная сторона, взаимосвяз, раскрытие информации

В отечественной бухгалтерии используют определенную документальную базу. Необходимо отметить, что в большей степени эта документальная база позволяет добиться соответствия общей идее МСФО.

Отношения со связанными сторонами способны влиять на финансовое положение и операционные итоги отчитывающегося лица. Международный стандарт финансовой отчетности (IAS) 24 «Раскрытие информации о связанных сторонах» преследует цель определить отношение и процедуры, которые могут проводить предприятие и связанные с ней стороны, с повышением раскрываемости [2].

В построении бизнеса нередко угадываются связанные стороны. Чаще всего они действуют едино на официальных основаниях, подтверждая это документально. Это важно для бухгалтерии и отчетности в налоговых органах, такие предприятия чаще всего оказываются наиболее способны к выживанию и сохранению своей способности к деятельности.

Высоко контролируются финансовые отчеты, по каждой связанной стороне, если они даны в отчетности.

Определения и термины признаются наиболее существенными, поскольку в зависимости от них формируются дальнейшие действия. Нет возможности устанавливать принадлежность в отношении организаций, не имеющих таких связей. Нельзя заявлять о связанных отношениях без документального подтверждения. Юридический статус требует, чтобы у вида разграничения оставалось больше своей терминологии, которая позволяет уточнять детали и делать решающие выводы.
Стороны признаются связанными, если одна из них имеет право контролировать другую, с возможным оказанием на нее значительного влияния в процессе принятия финансовых или операционных решений. Их можно уточнить по официальным параметрам:

- организации с непосредственным контролем за другой компанией или, наоборот, подконтрольные ей;

- ассоциированные предприятия;

- общими силами контролируемые предприятия;

- частные лица, с теми, которые являются близкими членами семьи, если они владеют прямо или косвенно пакетами акций, при праве голоса отчитывающегося предприятия, с возможностью воздействовать на деятельность компании;

- ключевой главенствующий состав штата, на который возложена ответственность за результаты и качество планирования, управления и контроля в отношении активности предприятия, когда стоит упомянуть и директоров и старших служащих, а также их родственников, близких членов их семей [3].

Важно учитывать, что связанными могут быть юридические и физические лица. Процессы между связанными сторонами по требованиям МСФО 24 нацелены на распределение возможностей или обязательств посреди связанных сторон. В процессе учитывается фактор взимания платы. В ряду операций - и те, которые касаются продажи и покупки товаров. Они могут осуществляться между независимыми сторонами. Есть доступ к проведению продажи или покупки различных существенных активов. 
Процессы достаточно разнообразны. Они связаны со всеми видами активности, если они связаны с передачей денег и внесением оплаты. Они осуществляются с подписанием определенных документов, что требует узаконивания всего процесса.

В коммерческой деятельности большинство действий связано с движением финансов. Регулярно осуществляется получение или передача денег. Стандартные взаимоотношения связанных сторон описаны законодательством, поскольку это отдельная сфера для бухгалтерии. Действия представляют собой актуальное явление в коммерции. Нередко предприятия проводят часть своей деятельности через дочерние организации подчиненного характера, ассоциированные компании, совместные фирмы и проч. В ряде случаев, стороны проводят операции на редких в их бизнесе условиях и по нетипичным ценам [4].
Контроль в любом случае обязателен. Обширность деятельности приводит ко множеству разногласий. Их приходится учитывать и тем или иным образом перерабатывать. Многие уже считают, что нужно обязать участников прописывать связь с другими участниками в своей учетной политике. Правило обязательно для ряда организаций, последствия такой связи зачастую имеют необоснованный противоправный характер. Часто прибегают к помощи третьих лиц, их задача - проверять отчетность участника и выявлять операции со связанными сторонами. Здесь уместно обращение к аудиторским компаниям, а также индивидуальные аудиторы. Остается помнить о том, что деятельность проверяющих должна быть полностью прозрачной, законной, профессиональной. Нужно обращаться в компании с большим опытом в своей сфере деятельности.

\section{Библиографический список}

1. Федорович Т.В., Дрожжина И. В. Проблемы формирования информации о финансовых результатах деятельности холдинга // Международный бухгалтерский учет. 2013. № 23 (269).

2. Федорович Т.В., Дрожжина И. В. Проблемы формирования отчетности по сегментам // Экономика железных дорог. 2015. № 7.

3. Кунгуров Ю.А., Федорович В.О. Финансовый менеджмент в условиях реформирования крупных производственных комплексов. Новосибирск: САФБД, 2014. 198 с.

4. Касьяненко Е.А. Формирование качественной учетной информации о финансовых результатах деятельности сельскохозяйственных организаций: автореф. дис. ... канд. экон. наук. Краснодар, 2014. 24 с. 